\title{
Hydraulic calculation of irrigation settling tanks of Amu Darya irrigation systems
}

\author{
Kenesbay Baimanov ${ }^{1}$, Kadirbek Nazarbekov ${ }^{2}$, Ruslan Baimanov ${ }^{1 *}$, and Sharap Tazhibayev ${ }^{1}$ \\ ${ }^{1}$ Karakalpak State University named after Berdakh, Karakalpakstan, Uzbekistan \\ ${ }^{2}$ Nukus State Pedagogical Institute named after Ajiniyaz, Karakalpakstan, Uzbekistan
}

\begin{abstract}
The Amu Darya river carries a large amount of up to $15 \mathrm{~kg} / \mathrm{m}^{3}$ of suspended matter containing up to $85-90 \%$ suspended and $10-15 \%$ bottom sediments, which pose a serious threat to the hydroelectric power station and irrigation systems operating in its basin. In case of dam water intake, head sump tanks are provided in the composition of waterworks. So, in the composition of Right-Bank and Left-Bank, sedimentation tanks with mechanical cleaning to protect the channels were built at the Takhiatash hydroelectric complex Kaskelenskaya and Selinsky irrigation system. It is established that the hydraulic and alluvial modes of operation of these settling tanks depend on the water, alluvial, and backwater modes of operation Takhiatash waterworks. It is noted that due to low water conditions, this hydroelectric power plant operated for a significant part of the year with fully closed gates in all spans, producing intensive siltation of the upper stream. These processes led to a change in the alluvial mode of operation of the settling tanks. At the same time, due to low water and excessive design dimensions, in the first years of operation, these settling tanks were heavily silted up, the bottom mark rose to $17.2 \mathrm{~m}$ (above the design $165 \mathrm{~m}$ ). Properly designed settling tanks should prevent siltation of main and distribution channels while respecting the transport capacity of the channels located below. It is proved that some well-known methods for calculating settling tanks, due to their complexity and bulkiness, cannot be used in calculating siltation modes of settling tanks under operational conditions that require simplification or finding a simpler relationship. A simple method is developed for calculating the dynamics of sediment deposition in irrigation sump tanks based on the probability of turbulent pulsation motion. Recommended: for normal operation of irrigation septic tanks, it is necessary to carry out systematic monitoring of the output turbidity and intensity of treatment, as well as water supply according to the water consumption schedule.
\end{abstract}

\section{Introduction}

The Amudarya river carries a large amount of suspended and bottom sediments, which pose a serious threat to hydroelectric power plants and irrigation systems operating in its basin. Sediment control is carried out by including special structures - sedimentation tanks

*Corresponding author: ruslan_kenesbaevich@list.ru 
characterized by large sizes and capital investments in their construction. Despite this, they are widely used in world practice.

Sediment deposition in sedimentation tanks is largely gradual and determined by the river's flow rate and water levels. The degree of clarification of water in the sump is determined based on the transport capacity of the protected channel [1].

In the case of dam less water intake in the Amudarya river, sediment management is mainly carried out by depositing excess amounts in the head sump tanks. These mechanically cleaned settling tanks are extended and deepened sections of the supply water intake channels (with multi-head water intake) or the head part of the main channel with a length of $1-5 \mathrm{~km}$. They should be located based on the convenience of storing sediments in the dump, taking into account the subsequent development of dumps [2,3]. In-system settling tanks should provide protection, as a rule, for a group of channels located below. It is recommended to use the instructions as in-system settling tanks along the channel route [2].

In the case of dam water intake, bottom and bottom sediments are not allowed into the channels, creating transverse circulation in the stream by artificially bending it in the plan. The most widespread water intake nodes are those with artificial curvature of the river section adjacent to the dam (Ferghana type). Considering the periods of intensive sediment entrainment to water intake structures, head settling tanks are provided.

In connection with the construction of hydroelectric power plants, the domestic regime of solid river flow is disrupted and же эксплуатации интенсивно the upper reaches are intensively silted up in the first years of operation бьефы. This process is strongly influenced by the режимаoperating mode of the head sump tanks.

In the composition of Right-Bank and left-Bank sedimentation tanks with mechanical cleaning to protect the channels were built at the Takhiatash hydroelectric complex Kaskelenskaya and Suenli irrigation system from heavy siltation. Both sump tanks are designed in two chambers with a dividing dam between the chambers. The length of the sump chamber is $750 \mathrm{~m}$, the width of each chamber along the bottom is $100 \mathrm{~m}$, and the depth is $10 \mathrm{~m}$. At the end of each chamber, reinforced concrete heads are built with two lines of repair and one working gate valve of the same design (two-section, wheeled). Both the left side and right side sedimentation tanks provide flow clarification from 23 to $48 \%$.

Analysis of these studies [5,6] mode clarification of flow in the upper reach of the node is shown that for the initial period of operation of the hydroelectric 1974-1981 due to the low water level and strong action of created to support the planned water intake channels in some decades of April, May, June, and August months there was clarification stream on average from 95 to $40 \%$ and overly bleached flow entering the channels, caused erosion of the streambed, disrupting the normal operation of the channels and the resulting decrease in the dormancy of azalea technical condition, especially the efficiency of the channel. During this period, the upper stream of the node played a kind of sump role, and intensivee sedimentation of sediments was observed in the area of the backwater curve.[5]

After five years of operation, Takhiatash hydroelectric complex sedimentation tanks were put into operation (1979) of this hydroelectric complex. Analysis of the hydraulic mode of operation of these settling tanks [7] showed that due to chronic low water and excessive cross-section, the average flow rate along the length of the settling chamber turned out to be very low compared to the design values, so during periods of turbidity intake greater, than the transport capacity, intensive siltation was observed along the entire length of the settling tanks. The cross-section survey data [7] showed that in the first years of operation of the settling tanks, intensive siltation occurred along the width and length of each chamber. Based on the results of our research, we recommend mechanical cleaning of the sump chambers with dredgers up to the bottom level of $171.0 \mathrm{~m}$ (against the design level of 165) in the amount of cleaning 400-450 thousand $\mathrm{m} 3$ per year. 
Poorly designed settling tanks in waterworks lead to high operational costs of funds and labor for cleaning structures from settled sediments.

The most important part of solving this complex problem is developing a reliable design method (mainly hydraulic calculation) for settling tanks. The most important issues, in this case, are the correct assignment of the size of the suspended sediment fraction coming out of the chamber and the correct determination of the size of the sump. A positive solution to the problem will be obtained only if the working length of the sump chambers is reliably determined, which ensures the deposition of the required amount of suspended particles of a given size.

To date, several methods have been proposed by A. N. Gostunsky [8], A. G. Khachatryan [1], P. V. Mikheev [9], Velikanova-Zegzhda [2], D. Ya.Sokolova [10], I. E. Mikhailova [11] for calculating settling tanks. A number of studies were devoted to the study of the alluvial regime of lowland rivers after the commissioning of hydraulic structures [188-2020].

For the design of irrigation sump tanks in the lower reaches of the river. имеют распространения методы расчета А. N. Gostunsky and A. G. Khachatryan's calculation methods are widely used in the Amudarya. Both theories are based on the assumption that each turbulent flow in the sump corresponds to a certain critical turbidity value and the composition of suspended sediments passing through "transit" without precipitation. The rest of the excess sediment entering the sump with water settles in it with the passage of time and - the faster, the larger the particles. EIf the critical turbidity is assumed to be the same for both methods, the sump length will be shorter [12].

In contrast to the methods of A. N. Gostunsky and A. G. Khachatryan, P. V. Mikheev's method [9] assumes that in a turbulent flow, all sediments simultaneously fall out at a lower rate than their hydraulic fineness.

The Velikanov-Zegzhda method described in [2] is based on the law of distribution of the averaged vertical pulsation velocity components acting on particles during their deposition. This method results in significantly overestimated sump lengths [11-20].

Direct Methods Sokolova and I. E. Mikhailova [21-35] are based on the experimental data of D. Ya. Sokolov. However, in his research, the range of issues studied was significantly limited. Therefore, these methods also contain assumptions that have no experimental justification.

The above calculation methods are complex and cumbersome to calculate; their adopted equations of the turbidity distribution curve cannot be universal for any sediment composition, which requires simplifying them or finding a simpler relationship since in operational conditions to regulate turbidity depending on the sediment intake, it is often necessary to determine the degree of clarification of the flow and the volume of siltation. Therefore, this issue needs more careful consideration and clarification [36-41].

\section{Methods}

In the process of research in the study of the hydraulic and superficial mode of head and onsite septic tanks in dam water are used in the conventional hydraulic methods, system analysis, statistical processing of research results to improve the efficiency of irrigation ponds in the lower reaches of the Amu Darya river.

The aim of the research was to study the operating mode of head and intra-system settling tanks; to measure the turbidity of the flow and cross-section along the length of sump; to study the siltation and cleaning mode of settling tanks; to observe the dynamics of sediment composition and content; to analyze the calculation methods of settling tanks.

During the field studies, the following characteristics were measured: level, water flow rate, and current velocity. Suspended sediment samples were sampled using a long-fill 
bottle bathometer, and entrained sediment samples were sampled using an instantaneous bathometer. Determination of the composition and content of sediments was carried out according to the instructions of SANIIRI. Fractional analysis was carried out by the hydraulic method using the pipette method with the separation of sediments by hydraulic fineness into 7 fractions.

\section{Results and discussion}

In sedimentation tanks of irrigation systems at flow rates $\vartheta=(0,2 \ldots .0,5) \mathcal{M} / c$, the fluid flow is turbulent, a characteristic feature of which is the presence of pulsating velocity components. In this regard, the horizontal length of the deposition path of particles of uniform hydraulic fineness passing through the input (initial) section at the same height is a random variable; that is, these particles do not fall out of the flow at one point, but are scattered along a certain length [9]. Knowledge of the law of deposition of the main parameters of particles and their distribution allows you to reliably determine the necessary working lengths for the deposition of a particular number of particles. In this case, it is recommended to determine the average length of the particle's trajectory by the well-known expression:

$$
L=\frac{\vartheta h}{W}
$$

Where $\mathrm{h}$ is the height of the particle arrangement at the beginning of the movement; $\vartheta_{\text {is }}$ the average flow rate in-depth $\mathrm{h} ; \mathrm{W}$ is the hydraulic particle size.

Formula (1) is very approximate since it is obtained for a rectangular channel, where the pulsation components of the velocity are negligibly small. A number of researchers have shown that particle precipitation will be inhibited by the presence of vertical components $\left|\bar{\vartheta}^{\prime}\right|$

. Therefore, the actual rate of precipitation of the suspension in the sump will $W_{0}=\left(W-\left|\bar{\vartheta}^{\prime}\right|\right)_{\text {be }}$ the suspension of the same size will be greater than when determining it from the speed W. Based on this, a coefficient is entered into formula (1) to determine the length of the sump $\alpha=W /\left(W-\left|\bar{\vartheta}^{\prime}\right|\right)$, after which the formula gets the form:

$$
L=\alpha \frac{\vartheta H}{W}
$$




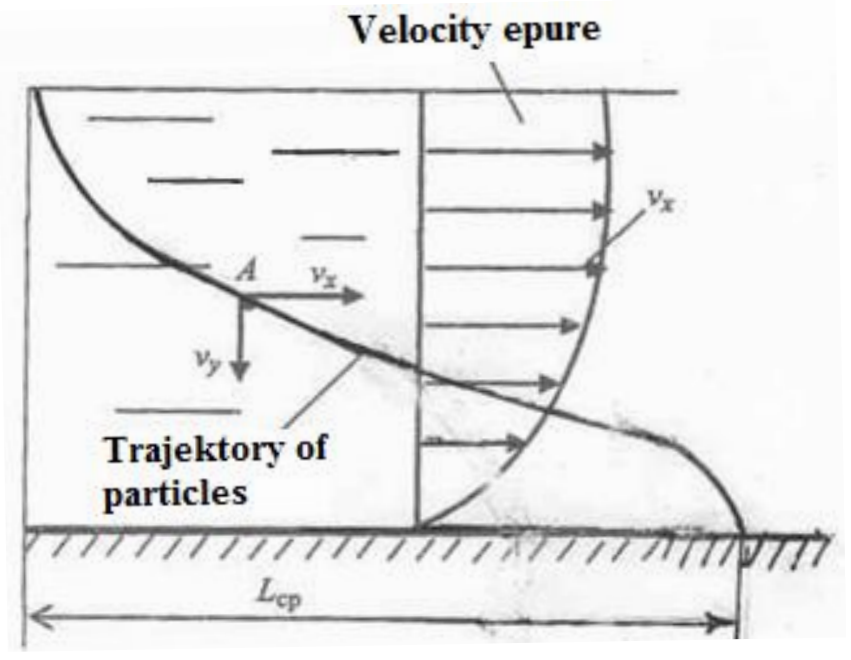

Fig.1. a diagram of the particle motion trajectory.

In Fig.1. a diagram of the particle deposition trajectory is shown with an uneven vertical distribution of flow velocities and a constant average velocity $\vartheta_{x}$ along the length [11]. The trajectory of the particle's fall is determined by the character of changes in the vertical flow rate.

Consider the motion of a particle located at point A. A particle having a horizontal direction and moving at a speed $\vartheta_{x}$ will travel a distance $d t$ in time $d x=\vartheta_{x} d t$. At the same time, this particle under the influence of gravity descends at a speed of $d z=\alpha \vartheta_{x} d t$. From here, we get the following equation:

$$
d x \vartheta_{x}=\alpha \vartheta_{z} d z \quad \text { or, } \quad d x=\alpha \vartheta_{z} / \vartheta_{x} d z
$$

which describes the trajectory of the particle's fall.

The requirements for settling tanks that protect irrigation channels are determined by the transport capacity of these channels. At the same time, the flow load of sediments carried out of the sump should not exceed the transport capacity of channels of different orders.

Theoretical development of the mechanism of weighing the sediment of the turbulent flow was given in the works of A. N. Goloskovo [8], S. H. Abalance [12], Yu. A. IbadZade [13], P. V. Mikheeva [9]on the basis of which scientists developed numerous empirical formula for calculating the carrying capacity of the stream for the design is not claimed and not eroded earthen channels.

Most formulas for determining the transport capacity of a stream can be reduced to the following convenient form:

$$
\rho=\eta \frac{\vartheta^{n}}{g R^{\alpha} W_{0}^{\beta}}
$$


Where $\mathrm{n}$ is proportionality coefficient, determined theoretically or experimentally; $\vartheta_{\text {is }}$ average flow rate, $\mathrm{R}$ is hydraulic radius; $\mathrm{W} 0$ is average hydraulic fineness; $\mathrm{n}, \alpha, \beta$ are exponents determined empirically.

The disadvantages of such formulas (4) are that in it the sediment composition is characterized through the average values of hydraulic fineness, which do not sufficiently characterize the granulometric composition of sediments, while the role of large fractions is especially lost.

Under many conditions, the water flow can be saturated to the limit with some fractions, oversaturated with the first, and under-saturated with the second, and non-saturated enough with the third. Observations of the turbidity regime of the Amu Darya river basin show that the flow is mostly under loaded with sediments with a hydraulic fineness of less than $2 \mathrm{~mm}$ I s (0 Studies of alluvial deposits covering the river bottom and channels [7] show that they mainly consist of fractions with a hydraulic fineness $\mathrm{W}>2.0 \mathrm{~mm} / \mathrm{s}$, and therefore the water flow can be considered extremely saturated only with these fractions.

The study of changes in the content of individual sediment fractions in sedimentation tanks of irrigation channels of the lower reaches of the Amudarya river showed that the content of the sediment fraction $\mathrm{W}<0.02 \mathrm{~mm} / \mathrm{s}$ during the deposition of the total turbidity to $70 \%$ and with a decrease in the flow rate to $\vartheta=0,20 \mathrm{M} / \mathrm{c}$ almost does not change. Thus, these fractions are carried in transit without precipitation, do not participate in the formation of the riverbed, and practically do not require mechanical energy for weighing them.

Analysis of field data also showed that the flow is capable of transporting a certain amount of sediment corresponding to hydraulic dimensions $\mathrm{W}>2.0 \mathrm{~mm} / \mathrm{s}, \mathrm{W}=2.0-0.20>$ $\mathrm{mm} / \mathrm{s}$, and $\mathrm{W}<0.20 \mathrm{~mm} / \mathrm{s}$, while weighing each fraction requires a certain proportion of the total pulsation energy $\left(\alpha \gamma \vartheta_{*} i\right)$.

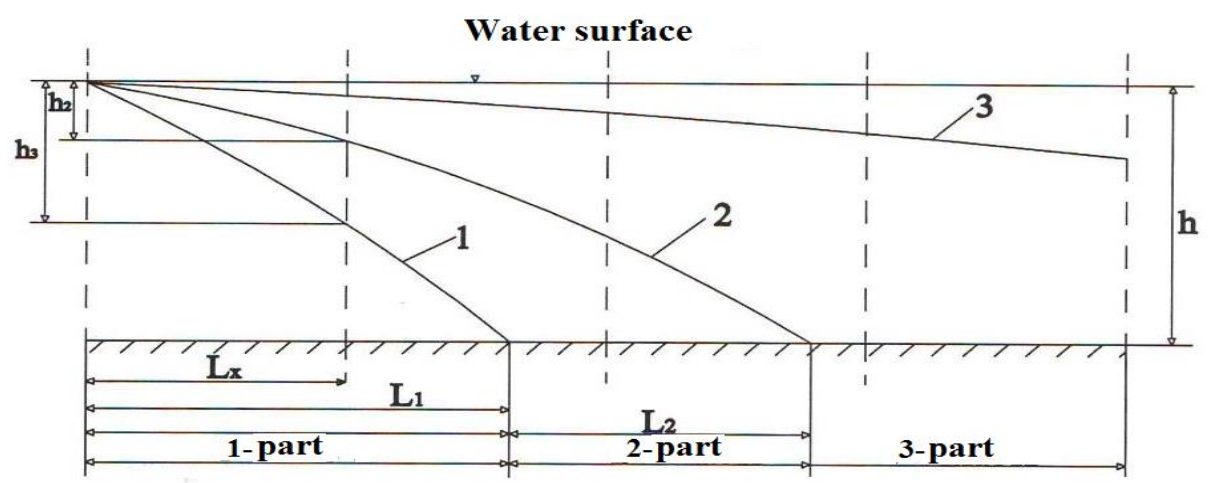

Fig. 2. The Trajectory and length of the deposition path of individual sediment particles with hydraulic fineness: 1 is $\mathrm{W}_{\mathrm{i}>2.0} ; 2$ is $\mathrm{W}_{\mathrm{i}=2.0-0.2} ; 3$ is $\mathrm{W}_{\mathrm{i}<2.0 \text {. }}$.

Figure 2 shows the trajectories of hydraulic-sized sediment particles falling from the surface layer

$W_{i}>2,0 ; W_{i}=2-0,2$ and $W_{i}<0,2 \mu M / c$. As can be seen from the figure, only the upper layer of the flow depth is completely released from the excess amount of sediments at a distance of Lx. 


$$
h_{\min }=\frac{W_{i}<0,2}{\vartheta} L_{x}, M
$$

Below this layer, a part of the excess turbidity sediments remains in the stream, the amount of which increases at the bottom. The values $W_{i}=2-0,2$ over the entire flow depth remain less than the maximum weighing speed $U_{6}$ (II-region). In this case, the value $W_{i}=2,0-0,2$ at a certain depth becomes equal to $U_{6}$, and this depth is equal to:

$$
h_{2}=\frac{U_{B}}{\vartheta} L_{2}
$$

The highest weighted flow rate is determined by the formula [1]:

$$
U_{в}=0,065(\vartheta-0,05) i^{114}
$$

In the initial section of the sump within $\mathrm{Lx}<\mathrm{L}$ (I-region), the value $W_{i}>2,0$; below the depth of h2 exceeds $U_{6}$ and reaches the highest hydraulic particle size of the initial turbidity at depth:

$$
h_{3}=\frac{W_{i>2}}{\vartheta} L
$$

Indicated in Fig.2, L1, L2, are characterize, respectively, the length of the precipitating particles of excess turbidity with dimensions $W_{i}>2 ; W_{i}=2,0-0,2 ; W_{i}<0,2 \mathrm{MM} / c$, determined by the formula (2).

Consequently, at a distance L, the flow is completely free of excess sediment. In any other alignment located at a distance of $\mathrm{Lx}<\mathrm{L}$, a certain amount of excess turbidity sediments remains in the stream $\rho_{u x}$. Therefore the total turbidity at a distance LX can be expressed as:

$$
\rho_{x}=\rho_{T}+\rho_{u x}
$$

Using equation (9), we can calculate the turbidity value at the outlet of the sump. In accordance with the above, it follows that the number of individual sediment fractions transported by the flow can be determined by the following formulas (Fig. 3): 


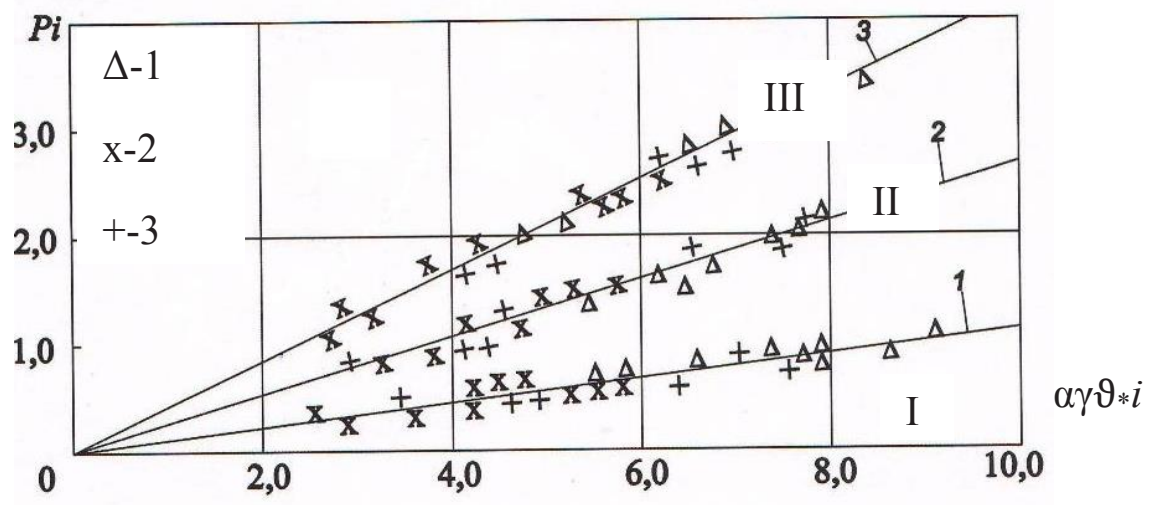

Fig. 3. Dependence of the critical turbidity content of individual sediment fractions on the inflow of pulsation energy $(\alpha \gamma \vartheta * \mathrm{i})$ : I-PI $>2>, 0$; II-PI=2.0-0.2; $\mathrm{m}$ III $-\mathrm{PI}<2.0$; 1-channel Kizketken irrigation system; 2-channelShenli; 3-channel Kegeyli.

within the I region

$$
\rho_{i>2,0}=0,125 \alpha \gamma \vartheta_{*} i
$$

within the II region

$$
\rho_{i=2,0-0,2}=0,28 \alpha \gamma \vartheta_{*} i
$$

within the third region

$$
\rho_{i<0,2}=0,42 \alpha \gamma \vartheta_{*} i
$$

where $\alpha \gamma \vartheta_{*} i$ is the work expended by the pulsating motion to maintain the suspension per unit time; $\alpha$ is the turbulence intensity coefficient in fractions of the dynamic velocity; $\vartheta_{*}=\sqrt{g R i}$ - dynamic velocity; $\gamma$ is the water density; i is the longitudinal slope of the water surface.

The total amount of sediment transported by the stream will be:

$$
\rho_{T}=\rho_{i>2}+\rho_{i=2,0-0,2}+\rho_{i<0,2}
$$

According to the current theoretical premise, the main factor in the weighing of solid particles is large-scale perturbations and, above all, the associated vertical components of the pulsation velocity. Solid particles can be suspended only when the vertical component of the pulsation velocity is greater than or equal to its hydraulic fineness. According to the research of K. I. Baymanov on irrigation channels of the lower reaches of the Amudarya River, the greatest hydraulic fineness of sediment particles weighed in the stream can be assumed to be equal to:

$$
W_{\max }=0,6 \vartheta_{*}=0,6 \sqrt{g R i}
$$

The root-mean-square value of the vertical component of the pulsating flow velocity, according to the experimental data of I. K. Nikitin [14], is close in magnitude to the dynamic velocity:

$$
\sqrt{/\left.\bar{\vartheta}^{\prime}\right|^{2}}=K \vartheta=\alpha \vartheta_{*}
$$


where $K$ is the turbulence intensity coefficient in fractions of the average flow velocity; $\left|\bar{\vartheta}^{\prime}\right|$-the vertical component of the pulsation velocity.

The analysis of the measurement data of vertical pulsation velocities in the channels of the Kizketken irrigation system showed that the values of $\mathrm{K}$ and $\alpha$ are not constant, but change depending on the shape, size of the channel, and the roughness of its surface [15].

Assuming that the sediment weighing is mainly due to the inflow of

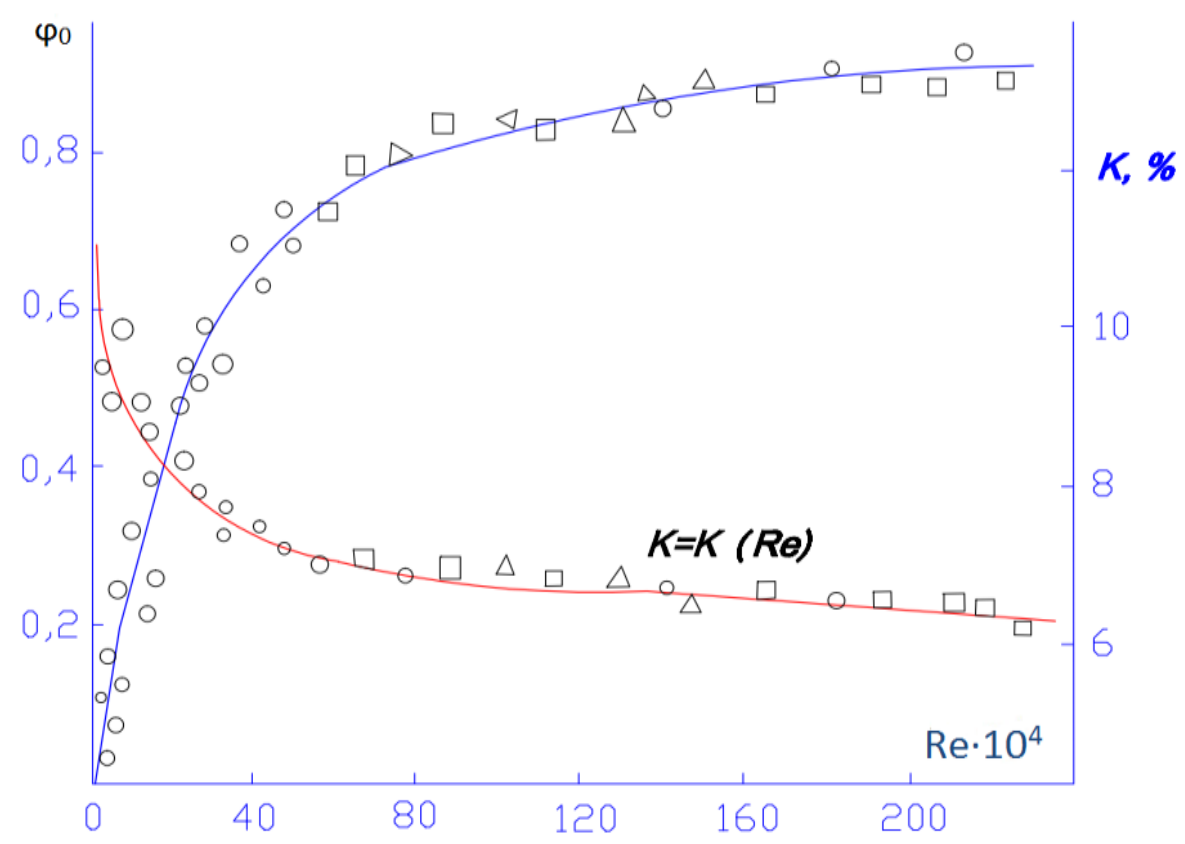

Fig. 4. Graph of the dependence of $\varphi_{o}=\varphi_{o}(R e)$ и $K=K(R e)$; $\mathrm{O}$ are channels Kizketken irrigation system (1952-1953); $\Delta$ is channel Paxtaarna (1964); $\square$ is channel Suyenli (1976-198181)

Taking the linear proportionality between the work required for weighing sediments and the work of the pulsation motion, we have [15]

$$
\delta \rho \bar{W}=\varphi K \gamma \vartheta i
$$

Substituting the value from $(15) K \vartheta$, we obtain

$$
\delta \rho \bar{W}=\varphi \alpha \gamma \vartheta_{*} i
$$

From here

$$
\rho_{T}=\varphi \frac{\alpha \gamma \vartheta_{*} i}{\delta \bar{W}}=\frac{\gamma \vartheta_{*} i}{\delta \bar{W}}
$$

Theoretical and practical justification of the formula (18) is described in detail in the article [15], using the determination of coefficient $\alpha$ is composed I. K. Nikitin [14] the 
graph of the vertical velocity component from the resistance coefficient, K. I. Baymanov built by the graph of $K=K(R e)$ (fig.4), which can $\alpha=K \vartheta / \vartheta_{*}$ be used to determine [1-55]

To determine $\varphi 0=\varphi \alpha$, the coefficient of the transport capacity of the flow, we used data from field measurements in the channels of the Amu Darya irrigation systems corresponding to the critical mode and compiled a graph $\varphi_{0}=\varphi_{0}(\mathrm{Re})$. When using formula (18), the values of $\varphi 0$ are determined according to the graph in Fig.4.

Thus, formula (18) is recommended for determining the critical turbidity of irrigation earth channels, and formulas (10-12) and (13) for calculating the sedimentation of sediment particles and excess turbidity fractions in the design of irrigation settling tanks. In this case, the equations of the dynamics of suspension deposition along the length of the sump, taking into account the balance of sediment deposition over time $t$ and the assumption of $\mathrm{P}$. V. Mikheev, can be presented in the following form [16]:

$$
\rho_{x}=\rho_{T}+\rho_{u x}=\rho_{T}+\left(\rho_{0}-\rho_{T}\right) \exp \left[-\frac{L W_{0}\left(\rho_{0}-\rho_{T}\right)}{h \vartheta \rho_{0}}\right]
$$

By determining the total turbidity $\rho_{x}$ at the outlet of the sump, you can calculate the degree of clarification of the flow $\varepsilon=\rho_{x} / \rho_{0}$, where P0 is the turbidity of the flow entering the sump, $\mathrm{kg} / \mathrm{m} 3$.

Thus, a simple method is obtained for calculating the dynamics of sediment deposition in irrigation sump tanks, taking into account individual fractional compositions of sediments corresponding to different hydraulic sizes. The proposed calculation method was verified based on field studies of several settling tanks [16].

\section{Conclusion}

Analysis of some existing theoretical and experimental studies by scientists in the CIS and abroad, as well as their own research on irrigation sump tanks, allows us to draw the following conclusions:

1. When designing irrigation sump tanks, it is necessary to apply calculated dependences of the connection of the hydraulic elements of the sump with alluvial and turbulent flow characteristics.

2. 2. Recommended known calculation methods due to their complexity and cumbersome calculations cannot be applied when calculating the operating modes of sedimentation tanks under operational conditions, which requires simplifying these methods of calculating sedimentation tanks or finding a simpler relationship of the hydraulic flow elements with the characteristics of the suspension.

3. Numerous studies have established that suspended particles of uniform hydraulic fineness are deposited and distributed at the bottom according to the normal Gauss law in a uniform turbulent flow. In this case, the average value of the deposition path length, taking into account the influence of pulsation, is determined by expression (2).

4. When calculating sediment transportation and sedimentation, it is advisable to use the distribution curves of the sediment composition by size. The number of individual sediment fractions is determined by the regular influence of velocity pulsation (Fig. 3).

5. Based on the research results, a simple method for calculating the dynamics of sediment deposition in irrigation sump tanks is obtained, taking into account the law of 
probability of turbulent pulsation motion corresponding to various hydraulic sizes of the sediment particle size distribution.

6. Analysis of studies of the hydraulic mode of operation of irrigation settling tanks showed the need for systto systematically monitorput turbidity and cleaning intensity. At the same time, the volume of purification up to LV should be regulated in conjunction with the volume of sediment deposition; an underestimation of this process leads to siltation of the sump and a decrease in flow clarification.

\section{References}

1. Khachatryan A.G., Shapiro X.Sh., Sharova Z.I., Zailenie i promiv irrigasionnix otstoynikov i vodoxranilitsh.-M. "Kolos". - p.238, (1966)

2. Instruktsiya po proektirovaniyu otstoynikov i nanosoperexvativayutshix soorujeniy dlya orositelnix sistem (VSP-11-15-77).- M.Stroyizdat. - p.64, (1977)

3. Kovalenko R.I. Issledovaniya metodov regulirovaniya zaileniya $\mathrm{v}$ golovnix otstoynikax Amudarinskix orositelnix sistem. Avtoref.diss.kand.texn.nauk.M., - p.18, (1977)

4. Shapiro X.Sh. Regulirovanie tverdogo stoka pri vodozabore v orositelnie sistemi.-M. "Kolos". - 270, (1983)

5. Baymanov K.I., Baymanov R.K. Issledovaniya pereformirovaniya podvodyatshego rusla verxnego befa Taxiatashskogo gidrouzla i usloviya protekaniya potoka v kanali //Problemi mexaniki AN RUZ №1-pp.13-17, Tashkent, (2010)

6. Baymanov K.I., Nazarbekov K.K. Issledovanie prosessov zaileniya i ochistki irrigasionnix otstoynikov //Vestnik ko AN RUZ. №1-2-pp.43-45, Nukus, (2004)

7. Baymanov K.I., Nazarbekov K.K., Baymanov R.K. Issledovanie rejima Raboti irrigasionnix otstoynikov v Nijnem techenii reki Amudarya//meliorasiya i vodnoe xozyaystvo.M., №2-pp.10-15, (2020)

8. Gostunskiy A.N. Vzveshivayutshaya sposobnost //Izv. AN UzSSR. №3-pp.59-68, Tashkent, (1954)

9. Mikheev P.V. Potoki i nanosi. Avtoref. diss.doktora texn.nauk-M. - p.32, (1952)

10. Sokolov D.Ya. Otstoynie basseyni dlya irrigasii i gidrostantsiy. M., Selxozgiz, p.444, (1945)

11. Mikhaylov I.E. Traektoriya i dlina puti osajdeniya vzveshinnix chastis //Gidrotexnicheskoe stroitelstvo. №1.pp.28-32, (2002)

12. Abalance S.X. Dvijenie nanosov v otkritix potokax //Trudi SANIIRI. VIP.96. - p.156, Tashkent, (1958)

13. .Ibad-Zade Yu.A., Nuriev Ch.G. Otstoyniki rechnix vodozaborov. M.,Stroyizdat. p.168, (1979)

14. Nikitin I.K. Issledovanie strukturi turbulentnogo potoka $\mathrm{v}$ kanalax irrigasionnoy seti //Trudi SANIIRI. VIP.91.- pp.55-76. Tashkent, (1958)

15. Baymanov K.I. O transportiruyutshey (vzveshivayutshey) sposobnosti potoka $\mathrm{V}$ irrigasionnix kanalax // meliorasiya i vodnoe xozyaystvo. M., №11-pp.37-39, (1989)

16. Baymanov K.I., Nazarbekov K.K., Baymanov R.K. Metod rascheta osajdeniya nanosov v irrigasionnix otstoynikax // Problemi mexaniki AN RUZ №3 - pp.22-27, Tashkent, (2019)

17. Baymanov K.I., Nazarbekov K.K. Efficiency of functioning of irrigation sinters //Collection of scientific Articles. LVI international correspondence scientific and practical conference- Boston, USA, 24-25. - pp.6-8, March, (2019)

18. Bazarov,D., Markova,I., Norkulov,B., Isabaev,K., Sapaeva,M. Operational efficiency of water damless intake.// IOP Conference series: Materials Science and Engineering -(2020).869(7). DOI:10.1088/1757-899x/869/7/072051. 
19. Krutov,A., Norkulov,B., Artucbekova,F., Nurmatov,P. Optimal location of an intake at a reservoir prone to salt diffusion // IOP Conference Series: Materials Science and Engineering -(2020).869.PP 072020.DOI: 10.1088/1757-899x/869/7/072020.

20. Raxmatov,N., Nazaraliev,D., Artucbekova,F., Uljaev,F., Sapaeva,M., Jumanov,O. Improving the efficiency of lead exploitation pumping station channels./IOP conference Series: Materials Science and Engineering- (2020) 883.-pp.012009.DOI: 10.1088/1757-899x/883/1/012009.

21. Bazarov D., Vatin N., Obidov B., and Vokhidov O. Hydrodynamic effects of the flow on the slab of the stand in the presence of cavitation. IOP Conf. Ser. Mater. Sci. Eng. 1030, 012110 (2021).

22. Bazarov D., Markova I., Norkulov B. and Vokhidov O. Hydraulic aspects of the layout of head structures during water intake from lowland rivers. IOP Conf. Ser. Mater. Sci. Eng. 1015, 012041 (2021).

23. Bazarov D., Markova I., Sultanov S. and Kattakulov F. Dynamics of the hydraulic and alluvial regime of the lower reaches of the Amudarya after the commissioning of the Takhiatash and Tuyamuyun hydrosystems. IOP Conf. Ser. Mater. Sci. Eng. 1030, 012110 (2021).

24. Bazarov D. and Vokhidov O. Extinguishing Excess Flow Energy in Spillway Structures. In book: Proceedings of EECE 2020, LNCE 150, pp. 535-545, (2021) DOI: 10.1007/978-3-030-72404-7_52

25. Bazarov D., Markova I., Norkulov B., Isabaev K., Sapaeva M. Operational efficiency of water damless intake. IOP Conf. Ser. Mater. Sci. Eng. 869(7), 072051, (2020)

26. Krutov A., Choriev R., Norkulov B., Mavlyanova D. and Shomurodov A. Mathematical modelling of bottom deformations in the kinematic wave approximation. IOP Conf. Ser. Mater. Sci. Eng. 1030, 012147 (2021).

27. Krutov A., Norkulov B., Uljaev F., and Jamalov F. Results of a numerical study of currents in the vicinity of a damless water intake. IOP Conf. Ser. Mater. Sci. Eng. 1030, 012121 (2021).

28. Krutov A., Norkulov B., Mavlyanova D. Simulation of spreading of non-conservative passive substances in water bodies. IOP Conf. Ser. Mater. Sci. Eng. 883(1), 012028 (2020)

29. Krutov A., Norkulov B., Nurmatov P., Mirzaev M. Applicability of zero-dimensional equations to forecast nonconservative components concentration in water bodies. IOP Conf. Ser. Mater. Sci. Eng. 883(1), 012028 (2020)

30. Krutov A., Norkulov B., Artikbekova F., Nurmatov P. Optimal location of an intake at a reservoir prone to salt diffusion. IOP Conf. Ser. Mater. Sci. Eng. 869(7), 072020, (2020)

31. Shokirov B., Norkulov B., Nishanbaev Kh., Khurazbaev M., Nazarov B. Computer simulation of channel processes. E3S Web of Conferences, 97, 05012, (2019)

32. Matyakubov B., Begmatov I., Raimova I. and Teplova G. Factors for the efficient use of water distribution facilities. IOP Conf. Ser. Mater. Sci. Eng. 883, 012025 (2020).

33. Uralov B., Rakhmatov N., Khidirov S., Uljaev F., Raimova I. Hydraulic modes of damless water intake. IOP Conf. Ser. Mater. Sci. Eng. 1030(1), 012123 (2021)

34. Bazarov D., Markova I., Raimova I., Sultanov Sh. Water flow motion in the vehicle of main channels. IOP Conf. Ser. Mater. Sci. Eng. 883, 012025 (2020).

35. Gur'ev,A.P., Kozlov D.V., Khanov N.V., Abidov M.M., Safonova N.A. Alternative Solutions for the Energy Dissipation of Idle Discharges at the Rogun HPP, Power Technology and Engineering, 2020, 54(1), pp. 7-12

36. Baranov E.V., Gur'yev A.P., Khanov N.V. Recommendations for Hydraulic Calculations of Anti-Erosion Lining with the Use of Spatial Geogrid with Coarse Fragmental Soil, Power Technology and Engineering, 2020, 53(5), pp. 553-556 
37. Khanov N.V., Martynov D.Y., Novichenko A.I., Lagutina N.V., Rodionova S.M. Outlook and Special Properties of Earth Anchors and Screw Piles in Burial of Modular Protection Dikes in Nonrocky Ground, Power Technology and Engineering, 2018, 52(4), pp. 405-412

38. Kurbanov S.O., Khanov N.V. To calculation of the critical depths of the canals with polygonal profile (PP)

39. Gidrotekhnicheskoe Stroitel'stvo, 2004, (3), pp. 42-44

40. Kurbanov S.O., Khanov N.V. To hydraulic calculation of the most favorable sections of the power diversion canals (PDC) of a polygonal profile, Gidrotekhnicheskoe Stroitel'stvo, 2003, (7), pp. 40-43

41. Khanov N.V. Hydraulic characteristics of chamber-free tangential vortex flow generators, Hydrotechnical Construction, 1999, 33(2), pp. 99-103 